\title{
Corporate Social Responsibility, Corporate Governance and Business Performance of Non-Financial Industry
}

\author{
Submitted 28/03/19, 1st revision 17/04/19, 2nd revision 19/05/19, accepted 25/07/19
}

\author{
Ting-Kun Liu ${ }^{1}$
}

\begin{abstract}
:
Purpose: In view of the past literatures on the impact of corporate social responsibility (CSR) on performance there are several with inconsistent conclusions, or with rare researches of the determinants of CSR. Besides, most of the literatures do not compare the efficiency with or without CSR, and related researches are either with short periods, or they only consider specific industries.

Design/Methodology/Approach: Therefore, this study constructs empirical data of financial industry in Taiwan from 2007 to 2016. First, we use the CommonWealth magazine "Corporate Citizenship Award TOP50" listed on the OTC Company's four indicators and the total score for the cross-industry analysis. Second, we construct the panel data model of the impacts of CSR and corporate governance on operating performance, and adopt other multi-variable considerations. Then, we divide into with or without CSR enterprises, and use data envelopment analysis (DEA) to analyze the differences of efficiency. Finally, we further examine the factors that affect the willingness of enterprises to invest in CSR.

Findings: The empirical results show that with the determinants of business performance, in ROA, ROE and EPS models, CSR is significant in non-financial industry samples. The DEA results show that CSR companies have better performance in non-financial industries. Finally, the results of enterprises willing to invest in CSR show that, in non-financial industry the larger the size of the company, the more willingness to invest in CSR.

Practical Implications: The research results may be implemented into managerial practices in order to improve and increase the business performance and efficiency of CSR companies. Originality/Value: The research studies the impact of corporate social responsibility (CSR) on performance and compares the efficiency with or without CSR from non-financial industries.
\end{abstract}

Keywords: Corporate social responsibility, corporate governance, business performance, panel data model, non-financial industries.

JEL Codes: G34, L20.

Article Type: Research study.

${ }^{1}$ Corresponding author, Associate Professor, Department of Finance, Chaoyang University of Technology, No.168, Jifeng E. Rd., Wufeng District, Taichung 41349, Taiwan, E-mail: tkliu@cyut.edu.tw 


\section{Introduction}

In recent years, the issue of corporate social responsibility (CSR) has gradually attracted the attention of the public. When the company pursues profitability, whether it can simultaneously return the profits to the society. ${ }^{2}$ In an age of dramatic changes in the global economy and environment, fulfilling CSR not only helps to accumulate operations, but also shares sustainable value with stakeholders. Taiwan Global Views Monthly and CommonWealth Magazine also held corporate social responsibility awards in 2005 for corporate social responsibility and the World Corporate Citizen Award from 2007. In the corporate governance, corporate commitment, social participation, environmental protection and other indicators, Tianxia Magazine selects the most future new value enterprise, and advocates that enterprises should not only be profitable tools, but also responsible citizens. In addition, in the 2008 CSR survey report of the University of Chicago Business School, $65.7 \%$ of consumers are willing to recommend the top 20 CSR companies to others, which is much higher than $25.9 \%$ of the last 20 CSR rankings. It shows that the higher the level of input CSR, the higher the consumer's evaluation, and the more successful the company. It can be seen that, while at home or abroad, it is an important issue for enterprises to improve their business performance while fulfilling CSR.

There is also a certain correlation between corporate governance and corporate social responsibility. If a well-established corporate governance mechanism is constructed, it will help enterprises implement social responsibility. In the past, there have been many financial frauds in large domestic enterprises, such as Donglong, Boda and Liba. It can be seen that their corporate governance is not perfect and there are some shortcomings. The Taiwan Stock Exchange and the China Corporate Governance Association have evaluated corporate governance for corporate governance indicators. The public information observatory also has a corporate governance zone to clearly disclose company-related information. Among the companies selected as the World Corporate Citizen Award, financial service-related companies are selected each year. Therefore, in today's increasingly concerned corporate social responsibility, will become an important driver of corporate social responsibility issues, while affecting other industries (Chi and Chen, 2004). It can be seen that corporate governance is an important factor in improving the economy and enhancing the competitiveness of enterprises. The impact of the implementation of CSR on company performance is also an issue worthy of further discussion.

Literatures of empirical study on CSR and company performance issues, Cai (2010) explores CSR's research on financial performance and economic indicators, and

\footnotetext{
${ }^{2}$ About the empirical studies of CSR, please refer to Yusoff et al. (2013), Lu et al. (2013), Cavaco, and Crifo (2014), Eabrasu (2015), Chen (2015), Oh and Park (2015), Dessy and Rosita (2015), Ye (2016), Yinyounget et al. (2016), Safwan and Zawawi (2016), Arouri and Pijourlet (2017), Matuszak and Różańska (2017), and Mishra, D. (2017).
} 
takes Taiwan and US award-winning companies as examples from 2006 to 2008. The empirical results show that CSR and corporate financial performance are not completely positive. Yusoff et al. (2013) explored the potential impact of the CSR structure on the company's financial performance. Based on stakeholder perspectives, a sample survey of 30 leading companies listed on the Bursa Malaysia exchange was conducted from 2009 to 2010. Lu et al. (2013) explore the relationship between CSR and company performance for the US semiconductor industry from 2004 to 2008. The results show that in the short term, the performance of CSR companies is lower than that of unimplemented. The reason for the poor business performance is that enterprises need to assume greater responsibilities and higher costs when implementing CSR.

Oh and Park (2015) explores the relationship between Korean CSR and the company's financial performance. The sample of the top 200 companies ranked in CSR in seven years is from 2004 to 2010. Research shows that CSR has different effects on corporate financial performance. Depending on the characteristics of each industry, companies should emphasize the strategic direction of companies to improve CSR to improve profitability and growth. Chen (2015) explores the impact of corporate governance and CSR on corporate performance. Taking Taiwan's food industry as an example, the results show that the relationship between CSR and corporate performance is negatively correlated. Dessy and Rosita (2015) explore the impact of environmental performance and CSR disclosure on financial performance, and studied cases of manufacturing, infrastructure and service companies listed on the Indonesia Stock Exchange from 2012-2013. It can be seen from the consolidation of the above-mentioned documents that the research period on CSR in the past is not long enough, or that only a single industry is discussed, and the conclusions on the implementation of CSR are also inconsistent.

The subject of corporate governance originated in the United States in the 1930s, and Asian countries gradually appealed to corporate organizations to pay attention to corporate governance systems after the 1997 financial turmoil. The main connotation is to enable the enterprise to effectively monitor its organizational activities and how to improve its organizational operations in order to achieve the goals of CSR through legal checks and balances and design. The OECD (International Organization for Economic Co-operation and Development) proposed the principle of corporate governance in 2004: "The corporate governance structure should be consistent with the laws and regulations, and clearly define the rights and responsibilities of different units to make the market more transparent, more efficient and fairer to all shareholders, interested parties, etc." Denis (2001) found that under the establishment of appropriate corporate governance mechanisms, it is indeed possible to effectively reduce managers' actions to undermine shareholder value.

Gheorghe (2012) explores the impact of corporate governance and banking performance in the Romanian banking industry, from 2004 to 2011. Studies have shown that the impact of bank performance is different from the development of 
banks, and that there are more stringent requirements in terms of equity, and the establishment of relevant default debtor regulations to limit risks to improve financial performance. Kim (2013) explores the impact of governance adequacy on firm performance. The research period was from 2005 to 2007. Empirical results show that the relationship between appropriate governance and firm performance is statistically significant. Zhang (2014) explores the relationship between corporate governance mechanism and business performance of Taiwan-listed electronics industry from 2008 to 2012, and the empirical results show that the shareholding ratio of major shareholders, the shareholding ratio of directors and supervisors ratio has no significant relationship with ROA. Chen (2015) explores the impact of corporate governance and corporate social responsibility on corporate performance of Taiwan's food industry from 2004 to 2012, and the empirical results show that the company's performance is better when the board size and director's shareholding ratio are larger. Chen (2015) explores the impact of corporate governance on the company's operating performance of food industry from 2006 to 2013 . The empirical results show that the directors (supervisory) shareholding ratio and earnings per share return results in a positive and significant level. Safwan and Zawawi (2016) explores if there is an optimal board structure. The evolutionary algorithm was used to analyze the FTSE Bursa Malaysia Composite Index from 2006 to 2009. The research results indicated that in terms of ROE and EPS, although the best board company outperformed the corresponding sample of the non-best board company, it was not significant.

From the discussion of the above literatures, it can be understood that most of the research on corporate governance in the past is limited to a single category of industry, and less cross-industry comparison analysis is carried out. Besides, domestic literatures, research on related corporate governance in the non-financial industry are also relatively rare compared to foreign literatures. In view of the past literatures the impact of corporate social responsibility (CSR) on performance, presented inconsistent conclusions with rare researches of the determinants of CSR. Besides, most of the literatures do not compare the efficiency with or without CSR, and related researches are either with short periods, or they only consider specific industries. Therefore, this study constructs empirical data of financial and nonfinancial industries in Taiwan from 2007 to 2016 for a further study.

\section{Research Methodology}

\subsection{Data Sources}

CommonWealth Magazine invites the public offering company that has been supervised by the Financial Supervisory Commission (FSC) for three consecutive years (2014-2016), the top 2000 survey vendors selected by CommonWealth Magazine, and local and foreign companies in Taiwan that experts and scholars recommend to participate. It is divided into four groups: large-scale enterprises, backbone enterprises, foreign-invested enterprises and small giants. The experts 
selected the top 100 companies in four aspects: corporate governance, corporate commitment, social participation and environmental protection.

This study selects the Taiwan-listed company that has won the World Corporate Citizen Award from the CommonWealth Magazine since 2007 as a research sample. In the same industry of the award-winning enterprise, we select an unwinned company as a paired sample for further compare and discuss. The study period is from the first quarter of 2007 to the fourth quarter of 2016, a total of 40 seasons. The total number of CSR-winning listed cabinet companies is 86 and 86 are unwinned companies with a total of 172 sample companies. Since the database of Taiwan Economic Journal (TEJ) does not contain foreign companies, this study excludes foreign companies, samples with insufficient years and data defects. In addition, because the automotive industry has fewer pairs of samples in the TEJ database, and most of the samples have a shorter number of years of establishment, there is one less company than the one that implements CSR. The sources of this research are TEJ, Common Wealth Magazine and Market Observation Post System form Taiwan.

\subsection{Variable Definition}

\subsubsection{Input and output terms of DEA}

The DEA variables in this study refer to the variables used in the past scholars' research, which are the basis for selecting input and output items. ${ }^{3}$ The financial and non-financial variables of this study are somewhat different due to different industrial attributes. (1) Financial industry: The input items are the number of employees, operating expenses, and fixed assets; the output items are operating income and interest income. For the description of each variable, please refer to Table 1. (2) Non-financial industry: Inputs are total assets, operating costs, total shareholders' equity, and number of employees; output items are total return on assets, return on equity, operating income, and net profit after tax. For the description of each variable, please refer to Table 2.

Table 1. Input and output variables of the financial industry

\begin{tabular}{cll}
\hline & Variable & \multicolumn{1}{c}{ Definition of variables } \\
\hline Number of employees & $\begin{array}{l}\text { Refers to the total number of employees in the } \\
\text { company. } \\
\text { Refers to the expenses that should be borne by the sales } \\
\text { of goods, provision of labor services or management } \\
\text { activities during the period. It is an important control }\end{array}$ \\
Input & item of the enterprise, including sales expenses, \\
terms & Fixagement expenses and research and development \\
& & $\begin{array}{l}\text { expenses. } \\
\text { Refers to the tangible assets held by an enterprise for } \\
\text { the purpose of producing goods, providing labor } \\
\text { services, renting or operating management, and having }\end{array}$ \\
& &
\end{tabular}

${ }^{3}$ See Fang (2010), Mihir et al. (2012), Chen (2014) and Wang (2015) for details. 


\begin{tabular}{|c|c|c|}
\hline & & a service life of more than one fiscal year. \\
\hline \multirow{4}{*}{$\begin{array}{c}\text { Output } \\
\text { terms }\end{array}$} & $\begin{array}{l}\text { Return on total } \\
\text { assets }\end{array}$ & $\begin{array}{l}\text { Refers to the ratio between the profit before interest } \\
\text { and taxes of the enterprise and the average total assets. }\end{array}$ \\
\hline & Return on equity & $\begin{array}{l}\text { The company creates profitable efficiency for the } \\
\text { overall shareholder funds. }\end{array}$ \\
\hline & Operating income & $\begin{array}{l}\text { Refers to the income from sales of goods or the } \\
\text { provision of labor services due to regular business } \\
\text { activities during the period, and the gross profit of sales } \\
\text { is deducted from sales and discounts. }\end{array}$ \\
\hline & Net profit after tax & $\begin{array}{l}\text { Refers to the net profit after tax minus the income tax, } \\
\text { which is the final surplus result of the company. }\end{array}$ \\
\hline
\end{tabular}

Table 2. Input and output variables of the non-financial industry

\begin{tabular}{|c|c|c|}
\hline & Variable & Definition of variables \\
\hline \multirow{4}{*}{$\begin{array}{l}\text { Input } \\
\text { terms }\end{array}$} & Total assets & $\begin{array}{l}\text { Refers to resources formed by past transactions or } \\
\text { events that are owned or controlled by the } \\
\text { enterprise and are expected to bring economic } \\
\text { benefits to the enterprise. }\end{array}$ \\
\hline & Operating cost & $\begin{array}{l}\text { Refers to the cost incurred in selling goods or } \\
\text { providing labor services due to regular business } \\
\text { activities during the period. }\end{array}$ \\
\hline & Total shareholders' equity & $\begin{array}{l}\text { Refers to the company's own funds, and the total } \\
\text { assets are deducted from the net residual value of } \\
\text { liabilities. }\end{array}$ \\
\hline & Number of employees & $\begin{array}{l}\text { refers to the total number of employees in the } \\
\text { company. }\end{array}$ \\
\hline \multirow{4}{*}{$\begin{array}{c}\text { Output } \\
\text { terms }\end{array}$} & Return on total assets & $\begin{array}{l}\text { Refers to the ratio between the profit before interest } \\
\text { and taxes of the enterprise and the average total } \\
\text { assets. }\end{array}$ \\
\hline & Return on equity & $\begin{array}{l}\text { The company creates profitable efficiency for the } \\
\text { overall shareholder funds. }\end{array}$ \\
\hline & Operating income & $\begin{array}{l}\text { Refers to the income from sales of goods or the } \\
\text { provision of labor services during the period due to } \\
\text { regular business activities, and the gross profit of } \\
\text { the business is deducted from the sales return and } \\
\text { discount. }\end{array}$ \\
\hline & Net profit after tax & $\begin{array}{l}\text { Refers to the net profit after tax minus the income } \\
\text { tax, which is the final surplus result of the } \\
\text { company. }\end{array}$ \\
\hline
\end{tabular}

\subsubsection{Variables of panel data model}

(1) Exploring the variables of corporate governance and CSR on business performance:

Dependent variables contain: a. Return on total assets (ROA): The higher the return on assets, the higher the profit on behalf of the overall assets. b. Return on equity (ROE): The higher the return on equity, the higher the profit that the company earns 
back for shareholders. c. Earnings per share (EPS): The higher the earnings per share represents the relatively high profitability of the company's capital per unit, so the better the company's profitability, the worthier of investment.

Independent variables include the following: a. Corporate Social Responsibility (CSR): For a dummy variable, the company that was selected as the World Corporate Citizen Award was 1; the unwinned company was 0. b. Corporate governance variables: Whether the chairman is concurrently the general manager; (Dual): Is a dummy variable, if the chairman has a concurrent general manager of 1 , otherwise 0 .

Rechner and Dalton (1991) found that the chairman and general manager can produce better financial performance. Pi and Timme (1993) found that when banks separate the positions of chairman and general manager, they will have lower asset costs and higher asset returns. The size of the board of directors referred to this study is the total number of board members. Bacon (1973) believes that the greater the size of the board, the more it can play its supervisory function. The major shareholder defined by the competent authority, that is, the shareholder who holds more than $10 \%$ of the shares but does not hold the position of director and supervisor.

Agrawal and Mandelker (1987) pointed out that when equity is concentrated on certain major shareholders, the greater the majority of shareholders, the more incentives to supervise the management, thereby increasing the value of the company. The ratio of the number of shares held by directors to the number of shares outstanding. Lu (2011) pointed out that the higher the shareholding ratio of directors, will help to improve the transparency of information disclosure in financial statements. The ratio of the number of shares held by the supervisor to the number of shares outstanding. Xie (1999) pointed out that the higher the shareholding ratio of supervisors, the more consistent with the interests of shareholders, the more they can play the supervisory function.

\section{Macroeconomic variables:}

a. The composite index of leading indicators (Index): The leading indicator composite index has the function of predicting future changes in the economy. When the leading indicator reaches the peak (or bottom), it can be expected that the peak will also peak (or bottom) after a period of time (Li, 2016) The study found that the leading index composite index has an impact on earnings per share, indicating that the boom cycle is an important indicator.

b. Annual real GDP growth rate (GDP): When the GDP growth rate is positive, it shows that the region's economy is in an expansion phase and the economic activity is more active.

\section{Fundamental variables:}

a. Year of establishment of the company (Age): That is, in 2016, the number of years of the company established by the company was subtracted. Peng et al. (2007) and 
Li (2006) pointed out that the company's establishment years will affect the company's operating performance.

b. Company size (Size): The size of the company referred to this study is the log value of the total assets. Chatterjee and Wernerfelt (1991) pointed out that the size of the firm has a considerable impact on the type of corporate strategy. If the scale is larger, it is easier to raise funds.

Financial variables:

Debt ratio (Debtratio): The debt ratio is the ratio of total liabilities to total assets and is an important indicator for measuring the capital structure of a company. Therefore, the debt ratio can roughly see whether a company's physical fitness is sound.

(2) Exploring the factors affecting companies' willingness to implement corporate social responsibility:

This study further explores the factors that companies are willing to invest in corporate social responsibility. Therefore, the following variables are constructed: The dependent variable is Corporate Social Responsibility (CSR), and the independent variables are included in the return on assets (ROA), return on equity (ROE), number of years of establishment (Age), size of the company (Size), and debt ratio (Debtratio) and the amount of capital paid (Capital).

\subsection{Description of Research Methods}

\subsubsection{Panel data analysis}

Panel Data has two different models: The first is the fixed effect model for situations where the cross-section and time series coexist in different samples with different intercepts. And the random effect model for samples where the cross-section and time series coexist, the intercept is random, so the error term is assumed to be a random coefficient.

\subsubsection{Data envelopment analysis (DEA)}

This study uses DEA to calculate efficiency values. The theory is from Farrell (1957) calculating the efficiency frontier with a non-predetermined production function. This efficiency front is the input and output value of all decision-making units (DMUs). The spatial relationship between the mathematical and mathematical methods, to find the boundaries of all the best possible points, as long as the DMU falls on the efficiency front, DEA sets its input and output combination is the most efficient, relative efficiency values range from 0 to 1 . However, DEA includes CCR and BCC modes. These two modes can be used to judge the scale compensation and other efficiency improvement information. The CCR model was first proposed by Charnes, Cooper and Rhodes in 1978.

\subsubsection{Logistic regression model}


In this study, logistic regression model was used to explore the factors that enterprises are willing to invest in CSR. Logistic model is used to predict the regression of strain number. It is applicable to the value of strain number as binary variable, and the number of strains only occurs $(\mathrm{Y}=1)$ and the event is not. Two results $(Y=0)$ occur. The Logistic model mainly considers the probability that each observation produces a specific result on the strain number under the influence of a set of independent variables (Cai and Wang, 2009).

\subsection{Empirical Model}

\subsubsection{Panel data model}

$$
\begin{aligned}
& \text { ROA }_{i t}=\beta_{0}+\beta_{1} \text { CSR }_{i t}+\beta_{2} \text { Dual }_{i t}+\beta_{3} \text { Bodsize }_{i t}+\beta_{4} \text { Bighold }_{i t}+\beta_{5} \text { Dirhold }_{i t}+\beta_{6} \text { Inshold }_{i t} \\
& +\beta_{7} \text { Index }_{i t}+\beta_{8} \text { GDP }_{i t}+\beta_{9} \text { Age }_{i t}+\beta_{10} \text { Size }_{i t}+\beta_{11} \text { Debtratio }_{i t}+\varepsilon_{i t} \\
& \text { ROE }_{i t}=\gamma_{0}+\gamma_{1} \text { CSR }_{i t}+\gamma_{2} \text { Dual }_{i t}+\gamma_{3} \text { Bodsize }_{i t}+\gamma_{4} \text { Bighold }_{i t}+\gamma_{5} \text { Dirhold }_{i t}+\gamma_{6} \text { Inshold }_{i t} \\
& +\gamma_{7} \text { Index }_{i t}+\gamma_{8} \text { GDP }_{i t}+\gamma_{9} \text { Age }_{i t}+\gamma_{10} \text { Size }_{i t}+\gamma_{11} \text { Debtratio }_{i t}+\mu_{i t} \\
& \text { EPS }_{i t}=\lambda_{0}+\lambda_{1} \text { CSR }_{i t}+\lambda_{2} \text { Dual }_{i t}+\lambda_{3} \text { Bodsize }_{i t}+\lambda_{4} \text { Bighold }_{i t}+\lambda_{5} \text { Dirhold }_{i t}+\lambda_{6} \text { Inshold }_{i t} \\
& +\lambda_{7} \text { Index }_{i t}+\lambda_{8} \text { GDP }_{i t}+\lambda_{9} \text { Age }_{i t}+\lambda_{10} \text { Size }_{i t}+\lambda_{11} \text { Debtrati }_{i t}+\tau_{i t}
\end{aligned}
$$

In the above formulas (1)-(3), the dependent variable includes total return on assets (ROA), return on equity (ROE), and corporate social responsibility (EPS). In terms of independent variables, it includes corporate social responsibility (CSR), whether the chairman is also the general manager (Dual), the board size (Bodsize), the major shareholding ratio (Bighold), the director shareholding ratio (Dirhold), the supervisor inshold ratio (Inshold), index of leading indicators (Index), annual growth rate of real GDP (GDP), company establishment year (Age), company size (Size), and debt ratio (Debtratio).

\subsubsection{Logistic model}

$\mathrm{CSR}_{i t}=\alpha_{0}+\alpha_{1}$ ROA $_{i t}+\alpha_{2}$ ROE $_{i t}+\alpha_{3}$ Age $_{i t}+\alpha_{4}$ Size $_{i t}+\alpha_{5}$ Debtratio $_{i t}+\alpha_{6}$ Capital $_{i t}+\tau_{i t}(4)$

In equation (4), the dependent variable is corporate social responsibility (CSR), and the independent variables include the following variables, total return on assets $(R O A)$, return on equity (ROE), age of company establishment (Age), size of company (Size), Debt ratio, and the amount of capital received (Capital).

\section{Empirical Results and Analysis}

\subsection{Analysis of the CommonWealth Magazine's Top 50 Corporate Citizens}


This section will use the CSR total score and four index scores of corporate governance, corporate commitment, social participation, and environmental protection to conduct cross-industry analysis for listed companies that have been selected as the CommonWealth Magazine Corporate Citizen Award.

\subsubsection{CSR overall sample analysis}

The industry that won the World Corporate Citizen Award, the largest number of which is the computer industry and peripheral equipment industry, a total of thirteen firms. The second is the semiconductor industry, a total of 12 firms, and the third is the financial industry, a total of nine firm. Among them, the technology industry (including semiconductors, electronic components, computers and peripherals, etc.) accounted for the largest number of award-winning companies.

\subsubsection{Total score analysis of CSR}

The total score of each industry in CSR is about 7.5 points on average. Among them, the highest total score is 8.06 points for the steel industry, followed by 7.9 points for the electronic components and communication network industry, and the third highest is 7.87 points for the computer and peripheral equipment industry. It shows that these industries are better in the overall performance of CSR, while the lower total score is 5.91 points for the rubber industry, indicating that there is room for improvement in the overall performance of CSR.

\subsection{Basic Statistics}

\subsubsection{Descriptive statistics}

This section is divided into a full sample of the panel data model, the DEA model for the non-financial industries, and the basic statistics of the variables of the Logistic model. For the basic statistics, please refer to Table 3. The correlation coefficient analysis of input and output variables refers to Table 4.

Table 3. Descriptive statistics of DEA model for non-financial industry

\begin{tabular}{ccccc}
\hline Input variable & Average & Standard deviation & Minimum & Maximum \\
\hline $\begin{array}{c}\text { Total assets } \\
\text { (million) }\end{array}$ & $78,015.01$ & $18,9792.4$ & 116 & 246,2715 \\
$\begin{array}{c}\text { Operating } \\
\text { costs } \\
\text { (million) }\end{array}$ & 17598.95 & $66,826.83$ & -12 & 1391,024 \\
$\begin{array}{c}\text { Shareholders' } \\
\text { equity } \\
\text { (million) }\end{array}$ & $37,867.54$ & $9,6236.45$ & 21 & 1283,893 \\
$\begin{array}{c}\text { Number of } \\
\text { employee }\end{array}$ & $15,260.09$ & $70,061.73$ & 4 & 995,000 \\
\hline $\begin{array}{c}\text { Output } \\
\text { Variable }\end{array}$ & Average & Standard deviation & Minimum & Maximum \\
\hline $\begin{array}{c}\text { Return on } \\
\text { total assets }\end{array}$ & 1.2263 & 2.6641 & -75.2 & 58.6 \\
\hline
\end{tabular}


$(\%)$

Return on

equity $(\%)$

Operating

income

(million)

Net profit

after tax

(million)
12.9714

$72,748.97$

$4,747.964$

$1,019.441$

$20,373.99$
$-585.7$

88.71

0

1500,105

$-26,565$

96,759

Table 4. Analysis of correlation coefficient of non-financial industry

\begin{tabular}{ccccccccc}
\hline & ROA & ROE & $\begin{array}{c}\text { Operating } \\
\text { income }\end{array}$ & $\begin{array}{c}\text { Net } \\
\text { profit } \\
\text { after tax }\end{array}$ & $\begin{array}{c}\text { Total } \\
\text { assets }\end{array}$ & $\begin{array}{c}\text { Operating } \\
\text { cost }\end{array}$ & $\begin{array}{c}\text { Shareholders' } \\
\text { equity }\end{array}$ & $\begin{array}{c}\text { number of } \\
\text { workers }\end{array}$ \\
\hline ROA & 1.0000 & & & & & & & \\
ROE & 0.9348 & 1.0000 & & & & & & \\
$\begin{array}{c}\text { Operating } \\
\text { income }\end{array}$ & 0.1679 & 0.2875 & 1.0000 & & & & & \\
$\begin{array}{c}\text { Net profit } \\
\text { after tax } \\
\text { Total }\end{array}$ & 0.6328 & 0.7021 & 0.7052 & 1.0000 & & & & \\
$\begin{array}{c}\text { assets } \\
\text { Operating } \\
\text { cost }\end{array}$ & 0.0691 & 0.1811 & 0.9361 & 0.6824 & 1.0000 & & & \\
$\begin{array}{c}\text { Shareholders' } \\
\text { equity }\end{array}$ & 0.1050 & 0.1683 & 0.9067 & 0.6938 & 0.9782 & 0.8986 & 1.0000 & \\
$\begin{array}{c}\text { Number of } \\
\text { employees }\end{array}$ & 0.0699 & 0.1786 & 0.8637 & 0.5641 & 0.8040 & 0.8624 & 0.7695 & 1.0000 \\
\hline
\end{tabular}

\subsubsection{Analysis of correlation coefficient}

When using the data envelopment analysis method, the input and output items must conform to the same direction. Therefore, this study examines the correlation between the selected inputs and the output items. The results show that the selected output items are positively correlated with the input items. Therefore, it can be inferred that the input and output variables selected in this study are reasonable and suitable for data envelopment analysis. For the correlation coefficient analysis, please refer to Table 4 .

\subsubsection{Test of optimal panel data empirical model}

This study used F-test, LM-test and Hausman-test to select the optimal empirical model for financial and non-financial industries. In the ROA model, the nonfinancial industry applies the fixed effect model. In the ROE model, the nonfinancial industry is suitable for the fixed effect model. In the EPS model, while the non-financial industry adopts random effects models. ${ }^{4}$

\subsection{Empirical Results of Determinants of Business Performance}

\footnotetext{
${ }^{4}$ However, because the CSR of this study is an important variable, the data of the fixed effect model cannot be displayed, so it is replaced by the random effect model.
} 


\subsubsection{Empirical analysis of the impact of ROA model}

As shown in Table 5, with respect to the non-financial industry, the promotion of CSR has a positive impact on ROA, indicating that for non-financial industry, the implementation of CSR is a factor affecting the company's business performance. The shareholding ratio of directors has a positive impact on ROA, indicating that the increase in shareholding ratio of directors can improve business performance. The size of the company has a positive impact on ROA, indicating that the larger the company's size, can improve business performance. The chairman of the board acts as the general manager, the annual growth rate of real GDP and the debt ratio.

Table 5. Empirical results of ROA, ROE and EPS models in non-financial industries

\begin{tabular}{ccccccc}
\hline & \multicolumn{2}{c}{ ROA } & \multicolumn{2}{c}{ ROE } & \multicolumn{2}{c}{ EPS } \\
\cline { 2 - 7 } Variable & Coefficient & P value & Coefficient & P value & Coefficient & P value \\
\hline CSR & 0.7238 & $0.000^{* * *}$ & 1.8908 & $0.008^{* * *}$ & 0.6564 & $0.010^{* * *}$ \\
Dual & -0.1750 & $0.088^{*}$ & -1.1094 & $0.028^{* *}$ & -0.2087 & $0.015^{* *}$ \\
Bodsize & 0.0003 & 0.991 & 0.1312 & 0.251 & 0.0747 & $0.002^{* * *}$ \\
Bighold & 0.0014 & 0.748 & -0.0646 & $0.004^{* * *}$ & 0.0104 & $0.008^{* * *}$ \\
Dirhold & 0.0260 & $0.000^{* * *}$ & 0.0427 & $0.033^{* *}$ & 0.0063 & 0.165 \\
Inshold & 0.0029 & 0.647 & -0.0189 & 0.579 & -0.0032 & 0.540 \\
Index & 0.0001 & 0.949 & 0.0389 & $0.012^{* *}$ & 0.0107 & $0.000^{* * *}$ \\
GDP & 0.0657 & $0.000^{* * *}$ & 0.0771 & $0.020^{* *}$ & 0.0161 & $0.001^{* * *}$ \\
Age & -0.0105 & 0.106 & 0.0146 & 0.524 & -0.0219 & $0.009^{* * *}$ \\
Size & 0.4789 & $0.000^{* * *}$ & 0.8614 & $0.033^{* *}$ & 0.5489 & $0.000^{* * *}$ \\
Debtrati & -0.0317 & $0.000^{* * *}$ & -0.1422 & $0.000^{* * *}$ & -0.0213 & $0.000^{* * *}$ \\
o & -1.6028 & 0.018 & -4.0389 & 0.176 & -3.1577 & 0.000 \\
Constant & $\mathrm{R}^{2}=0.1859$ & $\mathrm{R}^{2}=0.0450$ & $\mathrm{R}^{2}=0.1676$ \\
\hline
\end{tabular}

Note: ${ }^{* * *},{ }^{* *}$, and ${ }^{*}$ represent statistically significant levels of $1 \%, 5 \%$, and $10 \%$, respectively.

\subsubsection{Empirical analysis of the impact of the ROE model}

According to the results in Table 5, in the non-financial industry, the implementation of CSR has a positive impact on ROE, indicating that for non-financial industry, the implementation of CSR has a positive contribution to the company's business performance. The chairman of the board of directors as the general manager has a negative impact on ROE, showing that when the chairman is also a general manager, it is not conductive to the company's business performance. The shareholding ratio of major shareholders and the shareholding ratio of directors have a positive impact on ROE. This represents an increase in the shareholding ratio of major shareholders and the shareholding ratio of directors, which can improve business performance. Firm size has a positive impact on ROE, showing that the larger the company's size, can improve business performance. The debt ratio has a negative impact on ROE, indicating an increase in the debt ratio, which adversely affects the company's operating performance. The composite index of leading indicators and the annual growth rate of real GDP. 


\subsubsection{Empirical analysis of the impact of the EPS model}

As shown in Table 5, in the non-financial sector, the implementation of CSR has a positive impact on EPS, indicating that for non-financial industries, the implementation of CSR does affect the company's operating performance. The chairman of the board of directors as the general manager has a negative impact on EPS, showing that the chairman and the general manager are not conductive to the company's business performance. The positive impact on EPS shows that the increase in shareholding ratio of major shareholders can improve business performance. The composite index of leading indicators has a positive impact on EPS, showing that when the economy is better, it can improve the company's operating performance. The annual growth rate of real GDP has a positive impact on EPS, showing that the increase in the real GDP ratio can improve the company's operating performance. The company's size has a positive impact on EPS, indicating that the larger the company's size, can improve business performance. The debt ratio has a negative impact on EPS, indicating that the increase in the debt ratio is not conducive to the company's operating performance. The shareholding ratio of major shareholders is the same as that of the financial industry. The implementation of CSR is positive for the non-financial industry, this may be because the non-financial industry can directly present its performance through CSR because of its own operational needs.

\subsection{Data Envelopment Analysis Empirical Results}

Table 6 shows the efficiency values of CSR implemented in the non-financial industry. The results show that the total technical efficiency of the non-financial industry implementing CSR is better than that of the non-financial industry that has not implemented CSR. The efficiency value of the non-financial industry that implements CSR is observed by the industry. The total technical efficiency is better in the food, cement and other electronics industries. However, the poor performance is in shipping, plastics and tourism industries. The overall efficient company is 23 companies including Delta Electronics, Inc. The 13 companies such as LITE-ON Technology Corp. have declined in size, indicating that they can improve efficiency by reducing the scale.

In addition, 51 companies such as Far EasTone Telecommunications have increased their returns to scale, indicating that they can improve their efficiency by expanding their scale. The efficiency value of the non-financial industry that has not implemented CSR is observed by the industry. The total technical efficiency is better in the rubber, tourism and plastics industries. The less desirable performances are motor machinery, information services and biotechnology. The overall efficiency of the company is 25 companies such as Lingsen Precision Industries, Ltd., while the scale returns of 21 companies such as Microelectronics Technology Inc. are decreasing, and the returns of 40 companies such as Pan-International Industrial 
Corp. are increasing. Comparing the efficiency of the non-financial industry with or without CSR, the company's efficiency in implementing CSR is higher than that of companies that have not implemented CSR. Though the number of companies implement CSR with overall efficiency is less than companies with no implementing CSR. However, companies that do not implement CSR have a much larger number of companies with reduced returns to scale than those with CSR. Comparing the total technical efficiency values of the financial industry and the non-financial industry, the performance of the financial industry is better than that of the nonfinancial industry. This means that the financial industry can make full use of resources.

Table 6. The efficiency whether the non-financial industry implements CSR

\begin{tabular}{cccc}
\hline $\begin{array}{c}\text { Non-financial } \\
\text { industry }\end{array}$ & overall efficiency & Pure efficiency & Scale efficiency \\
\hline Implemented CSR & 0.889 & 0.972 & 0.912 \\
Not implemented CSR & 0.888 & 0.900 & 0.987 \\
\hline
\end{tabular}

Note: The numerical values in the table are the average of the non-financial industry.

\subsection{Logistic Model Empirical Results}

Table 7 shows the empirical results of the Logistic model of the financial and nonfinancial industries. In the financial industry, the return on equity returns has a positive impact on CSR, indicating that the increase in the return on equity can increase the willingness of companies to commit to CSR. The number of years of establishment of the company has a negative impact on CSR, indicating that the longer the company is established, the lower the willingness of enterprises to invest in CSR. The debt ratio has a positive impact on corporate social responsibility, indicating that the higher the debt ratio, the higher the willingness of companies to implement CSR. The amount of paid-in capital has a negative impact on corporate social responsibility, indicating that the higher the paid-in capital, the lower the willingness of enterprises to invest in CSR.

Regarding the non-financial industry, the return on total assets has a positive impact on CSR, indicating that the increase in the total return on assets can increase the willingness of companies to invest in CSR. The size of the company has a positive impact on corporate social responsibility, indicating that the larger the company's size, the greater the willingness to invest in CSR. The amount of paid-in capital has a positive impact on corporate social responsibility, indicating that the higher the paid-in capital, the higher the willingness to invest in CSR.

Comparing the factors that the financial industry and the non-financial industry are willing to invest in CSR, there is a significant difference between them. In terms of the amount of paid-in capital, the higher the amount of paid-in capital in the 
financial industry, the lower the willingness of enterprises to invest in CSR, while the non-financial industry is rise. In terms of financial ratio, the factors affecting the financial industry's investment in CSR are the return on equity and debt ratio, while the non-financial industry is the return on total assets. As a result, the difference in industrial characteristics can be further understood, and the factors that are willing to invest in CSR will be different.

However, for the financial industry and the non-financial industry, the increasing size of the company has increased the willingness to invest in CSR. This variable has the same direction of influence on the above two industries. This result also shows that in the real society, large enterprises should have more resources, tolerance and higher willingness than small enterprises to further implement CSR.

Table 7. Empirical results of the logistic model of non-financial industries

\begin{tabular}{lcc}
\hline & & non-financial industries \\
\cline { 2 - 3 } & Coefficient & P-value \\
\hline ROA & 0.2114 & $(0.000)^{* * *}$ \\
ROE & -0.0016 & $(0.708)$ \\
Year of & 0.0002 & $(0.880)$ \\
establishment & & \\
Size & 0.6566 & $(0.000)^{* * *}$ \\
Debt ratio & -0.0026 & $(0.124)$ \\
Paid-up capital & 0.6522 & $(0.000)^{* * *}$ \\
Constant & -11.1823 & $(0.000)^{* * *}$ \\
\hline Log likelihood & -3996.7736 & \\
LR chi2(6) & 1359.56 & \\
\hline Note $^{* * * * * *}, d^{*}$ &
\end{tabular}

Note: ${ }^{* * *},{ }^{* *}$, and $^{*}$ represent statistically significant levels of $1 \%, 5 \%$, and $10 \%$.

\section{Conclusion and Recommendations}

Empirical results of determinants of business performance:

The empirical results of the ROA, ROE and EPS models show that the implementation of CSR in the non-financial industry sample has reached a significant level, and the implementation of CSR on behalf of non-financial companies can improve performance. For the non-financial industry, this has the effect of positive, encouraging and inspiring. If the chairman is also the general manager, it will have a significant negative impact on the non-financial industry. This means that when the chairman of the board also acts as the general manager, it is too likely to lose its objectivity and the power of supervision because it plays the role of decision-makers and supervisors at the same time, which has a negative impact on the company's performance. Regarding the macroeconomic variables, the annual growth rate of GDP is positive in the non-financial industry. The empirical results of the above variables imply that when the national economy or prosperity is better, the company operating performance can be a significant benefit. 
Empirical results of DEA:

We compare the non-financial industry's efficiency in implementing CSR. By observing the total technical efficiency value, companies with CSR have higher efficiency than those without CSR. It can be seen that companies with CSR perform relatively well. In companies that have not implemented CSR, the number of companies with reduced returns to scale is much higher than the number of companies that implement CSR.

Empirical results of factors that companies are willing to invest in CSR:

The factors that the non-financial industry is willing to invest in CSR are significantly different. The higher the paid-in capital of the non-financial industry in terms of the amount of paid-in capital, the higher the willingness of enterprises to invest in CSR. In terms of the financial ratio variable, the factors affecting the nonfinancial industry's investment in CSR is the return on total assets. In addition, for the non-financial industry, the company's larger scale will increase the willingness to invest in CSR.

The empirical results indicate that implementation of CSR in non-financial companies can improve performance. It means that the non-financial industries' enterprises can have good business results on the one hand, and social responsibility can be promoted on the other. Regarding the empirical aspects of DEA efficiency, the results fully show that companies that have implemented CSR, in the nonfinancial industries, are significantly more efficient and productive than those that have not implemented CSR.

Therefore, it is recommended that companies should be brave in implementing CSR, and relevant government agencies should also develop relevant policies to coach, motivate and promote CSR. In addition to encouraging large companies, large enterprises should have more resources, tolerance and higher willingness than small enterprises to further implement CSR. Therefore, the relevant units of the government should aim at companies that are willing to promote CSR for small and medium-sized enterprises. They can use policies such as rewards, counseling and subsidies to help small and medium-sized enterprises (SMEs) to learn to undertake social responsibilities while fighting for economics. It is also possible to publicize the public through the public power. In addition to rewarding and encouraging CSR to promote excellent manufacturers, it also encourages the public to purchase more CSR certified stores. This move will contribute to the positive cycle of social, industrial and economic aspects.

Finally, in terms of follow-up research recommendations, this study uses the same industry as the matching standard for the selection of CSR paired samples, so it is recommended that future researchers can further match according to the size of the company. Since the source of the data is limited to TEJ, this article cannot obtain the information of the foreign company in the world corporate citizenship award. 
Therefore, it is recommended that future researchers may consider the foreign company to be discussed, or to compare the efficiency and productivity of foreign companies and domestic companies. In addition, as the number of award-winning companies in the electronics industry is large, future research may consider crossindustry comparisons between the electronics industry and the non-electronics industry.

\section{References:}

Agrawal, A. and Mandelker, G.N. 1987. Managerial Incentives and Corporate Investment and Financing Decisions. Journal of Finance, 42(4), 823-837.

Arouri, M. and Pijourlet, G. 2017. CSR Performance and the Value of Cash Holdings: International Evidence. Journal of Business Ethics, 140(2), 263-284.

Bacon, J. 1973. Corporate Directorship Practices: Membership and Committees of the Board, The Conference Board and American Society of Corporate Secretaries, New York.

Banker, R.D., Charnes, A. and Cooper, W.W. 1984. Some Models for Estimating Technical and Scale Inefficiencies in Data Envelopment Analysis. Management Science, 30 (9), 1078-1092.

Cai, Y.Q. 2010. The Study of The Relationship Between Financial Performance and Economic Indicators of Corporate Social Responsibility is Based on Taiwan and The US Award-Winning Companies, Master's thesis, National Chin-Tech University.

Cai, Y.H. and Wang, Z.C. 2009. Analysis of the Correlation between Corporate Governance and Corporate Cabinets in Taiwan. Journal of Trade and Industry, 1(1), 41-56.

Cavaco, S. and Crifo, P. 2014. CSR and Financial Performance: Complementarity between Environmental, Social and Business Behaviours. Applied Economics, 46(27), 33233338.

Caves, D.W., Christensen, L.R. and Diewert, W.E. 1982. The Economic Theory of Index Numbers and the Measurement of Input, Output and Productivity. Econometrica, 50 (6), 1393-1414.

Charnes, A., Cooper, W.W. and Rhodes, E. 1978. Measuring the Efficiency of Decision Making Units. European Journal of Operational Research, 2(6), 429-444.

Chatterjee, S. and Wernerfelt, B. 1991. The Link between Resources and Type of Diversification: Theory and Evidence. Strategic Management Journal, 12(1), 33-48.

Chen, G.D. 2015. The Impact of Corporate Governance and Corporate Social Responsibility on Corporate Performance-Taking Taiwan's Food Industry as an Example. Master's thesis, Nantai University of Science and Technology.

Chen, H.G. 2013. Research on the Relationship between Corporate Governance, Breakthrough Innovation and Business Performance - Taking Taiwan's Semiconductor Industry as an Example. Master's thesis, Tokai University.

Chen, Y.R. 2014. Information Disclosure Transparency, Corporate Governance and Business Performance-Taiwan's Financial and Food Industry Cross-Industry Evidence. Master's thesis, Chaoyang University of Science and Technology.

Chen, Y.Z. 2015. The Impact of Corporate Governance on the Company's Business Performance - Taking the Food Industry as an Example. Master's thesis, National Kaohsiung University of Applied Sciences.

Chi, X.L. and Chen, T.T. 2004. Discussion on Corporate Social Responsibility in Banking. Taiwan Financial Finance Quarterly, 5(2), 111-127.

Denis, D.K. 2001. Twenty-five Years of Corporate Governance Research and Counting. Review of Financial Economics, 10(3), 191-212. 
Dessy, A. and Rosita, S. 2015. The Effect of Environmental Performance and Corporate Social Responsibility Disclosure Towards Financial Performance (Case Study to Manufacture, Infrastructure, and Service Companies that Listed at Indonesia Stock Exchange). Procedia - Social and Behavioral Sciences, 211, 348 -355.

Eabrasu, M. 2015. Post Hoc Ergo Propter Hoc: Methodological Limits of PerformanceOriented Studies in CSR. Business Ethics: A European Review, 24, S11-S23.

Fang, J. 2010. Bank Performance Analysis of Taiwan and China. Master's thesis, National Taiwan University.

Farrell, M.J. 1957. The Measurement of Productive Efficiency. Journal of the Royal Statistical Society, 120(3), 253-281.

Fare, R., Grosskopf, S. Norris, M. and Zhang, Z. 1994. Productivity Growth, Technical Progress, and Efficiency Change in Industrialized Countries. The American Economic Review, 84(1), 66-83.

Gheorghe, C. 2012. Corporate Governance and Bank Performance in the Romanian Banking Sector. Procedia Economics and Finance, 3, 549-554.

Harjoto, M. and Jo, H. 2015. Legal vs. Normative CSR: Differential Impact on Analyst Dispersion, Stock Return Volatility, Cost of Capital, and Firm Value. Journal of Business Ethics, 128(1), 1-20.

Hausman, J.A. 1978. Specification Tests in Econometrics. Econometrica, 46(6), 1251-1272. Huang, X.Y. 2010. The Impact of Corporate Governance Quality and Business Strategy on Business Performance-As an Example of a Listed Cabinet Company that Has Passed the Corporate Governance Assessment of the China Corporate Governance Association. Master's thesis, National Taipei University.

Kim, D.H., Kim, J. Byun, Y. and Chun, S.H. 2013. A Study on the Effect of Governance Adequacy on the Corporate Performance. Procedia -Social and Behavioral Sciences, 107, 59-66.

Li, J.Z. 2006. Research on the Relationship between Corporate M\&A and Operational Performance - Taking Taiwan-listed Companies as an Example. Master's thesis, National Chenggong University.

Li, S.G. 2016. Study on the Relationship between Overall Economy, Economic Cycle Factors and Bank Performance. Chinese Journal of Management Review, 19(2).

Lu, W.M., Wang, W.K. and Lee, H.L. 2013. The Relationship between Corporate Social Responsibility and Corporate Performance: Evidence from the US Semiconductor Industry. International Journal of Production Research, 51, 5683-5695.

Lu, Y.M. 2011. Board Characteristics and Information Transparency. Master's thesis, National Kaohsiung University of Applied Sciences.

Matuszak, L. and Różańska, E. 2017. An Examination of the Relationship between CSR Disclosure and Financial Performance: The Case of Polish Banks. Accounting \& Management Information Systems / Contabilitate si Informatica de Gestiune, 16(4), 522-533.

Mihir, D. and Christabel, C. 2012. An Analysis of the Technical Efficiency of Banks in India. The IUP Journal of Bank Management, 11, 100-109.

Mishra, D. 2017. Post-innovation CSR Performance and Firm Value. Journal of Business Ethics, 140(2), 285-306.

Oh, W. and Park, S. 2015. The Relationship Between Corporate Social Responsibility and Corporate Financial Performance in Korea. Emerging Markets Finance \& Trade, 51, 85-94.

Pi, L. and Timme S.G. 1993. Corporate Control and Bank Efficiency. Journal of Banking and Finance, 17, 515-530. 
Peng, M.W., Zhang, S. and Li, X. 2007. CEO Duality and Firm Performance During China's Institutional Transitions. Management and Organization Review, 3, 205-225.

Rechner, P.K. and Dalton, D.R. 1991. CEO Duality and Organizational Performance: A Longitudinal Analysis. Strategic Management Journal, 12(2), 155-160.

Safwan, M.N. and Zawawi, N.H.M. 2016. Is There an Optimal Board Structure? An Analysis Using Evolutionary Algorithm on the FTSE Bursa Malaysia KLCI. Procedia Economics and Finance, 35, 304-308.

Wang, L. 2015. Using Data Envelopment Analysis (DEA) for Business Performance Evaluation in the Electronic Component Industry. Master's thesis, National Central University.

Xiao, P.C. 2016. Efficiency and Productivity of Taiwan's Pan-Public and Non-Public BanksAnalysis of the Implementation of the Financial Holding Company Law. Master's thesis, Chaoyang University of Science and Technology.

Xie, W.X. 1999. Relationship between family business control mechanisms and management in management. Master's thesis, Soochow University.

Ye, J.X. 2016. Relationship between Corporate Social Responsibility and Financial Performance of Taiwanese Banking Industry. Master thesis, China Culture University, Taipei City.

Yusoff, H., Mohamad, S.S. and Darus, F. 2013. The Influence of CSR Disclosure Structure on Corporate Financial Performance: Evidence from Stakeholders. Perspectives. Procedia Economics and Finance, 7, 213-220.

Yin-Young, R., Manisha, S. and Yoon, K. 2016. CSR and Financial Performance: The Role of CSR Awareness in the Restaurant Industry. International Journal of Hospitality Management, 57, 30-39.

Zhang, W.T. 2014. Relationship between Corporate Governance Mechanism and Business Performance-Taking Taiwan's Listed Electronics Industry as an Example. Master's thesis, National Yunlin University of Science and Technology. 